\title{
Reflexões sobre a qualidade da água de abastecimento público em Nossa Senhora do Livramento-MT
}

\section{Reflections of the quality of puplic supply water in Nossa Senhora do Livramento-MT}

\author{
Alysson Morais da Silva ${ }^{1^{*}}$, Carla Maria Abido Valentini ${ }^{2}$ \\ 1 Acadêmico do curso de Engenharia Sanitária e Ambiental, Universidade Federal de Mato Grosso, Mato Grosso, Brasil. \\ https://orcid.org/0000-0002-1454-6747 E-mail: jrmoraisengenharia@gmail.com *Autor de correspondência \\ ${ }^{2}$ Graduação em Licenciatura em Ciências / Habilitação em Química pela Universidade Federal de Mato Grosso, Mestrado em Física e Meio \\ Ambiente pela Universidade Federal de Mato Grosso e Doutorado em Agricultura Tropical pela Universidade Federal de Mato Grosso. \\ Professora Titular e orientadora de pesquisa no Instituto Federal de Educação, Ciências e Tecnologia de Mato Grosso (IFMT), campus \\ Cuiabá-Bela Vista. Brasil. https://orcid.org/0000-0002-0943-2868 E-mail: carla.valentini@blv.ifmt.edu.br
}

\author{
Palavras-chave \\ Poços tubulares \\ Qualidade da água \\ Cloração \\ Padrão de potabilidade da água \\ Tratamento de água
}

\begin{abstract}
A qualidade da água que abastece uma cidade é fundamental para a saúde de seus moradores. No município de Nossa Senhora do Livramento, MT, o abastecimento público é feito com águas de poços tubulares, porém alguns moradores idosos expressaram descontentamento quanto ao gosto e ao cheiro da água que chega às suas torneiras. Dessa forma, o objetivo desse trabalho foi realizar medidas físico-químicas e microbiológicas em pontos que pudessem dar uma possivel resposta a essa demanda. As medidas foram realizadas em 12 pontos, que incluíram o poço tubular principal da cidade, o reservatório do Departamento de Água e Esgoto e os cavaletes das casas desses moradores ou próximos a elas. As medidas físico-químicas foram realizadas in loco, em setembro e novembro de 2018 e fevereiro de 2019, usando-se um fotômetro multiparâmetro e um turbidímetro, e as microbiológicas em laboratório pela técnica de membrana filtrante. Os resultados apontaram que tanto o teor de cloro como a maioria dos parâmetros avaliados estavam dentro do que preconiza a PCR MS $n^{\circ}$ 05/17, Anexo XX. No entanto, é importante atentar-se às reclamações dos consumidores quanto ao gosto $e$ ao odor de substâncias na água, porque podem apontar falhas no tratamento da água ou de contaminação na própria rede.
\end{abstract}

\section{Keywords}

Tubular wells

Water quality

Chlorination

Water potability pattern

Water treatment

\begin{abstract}
The quality of the water that supplies a city is fundamental to the health of its residents. In the municipality of Nossa Senhora do Livramento, MT, public supply is made with water from tubular wells, but some elderly residents expressed dissatisfaction with the taste and smell of the water that reaches their taps. Thus, the objective of this work was to carry out physical-chemical and microbiological measures at points that could give a possible answer to this demand. Measurements were taken at 12 points that included the main tubular well in the city, the Department of Water and Sewage reservoir and the easels in or near the homes of these residents. Physical-chemical measurements were carried out on the spot, in September and November 2018 and February 2019, using a multiparameter photometer and a turbidimeter, and microbiological measurements in the laboratory using the filtering membrane technique. The results showed that both the chlorine content and most of the parameters evaluated were within the limits of PCR MS no 05/17, Annex XX. However, it is important to pay attention to consumer complaints regarding the taste and odor of substances in the water, as they may point out flaws in the water treatment or contamination in the network itself.
\end{abstract} .

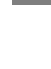

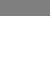


Segundo o Sistema Nacional de Informações sobre Saneamento (BRASIL, 2018), dos 5.565 municípios brasileiros, atualmente $83,6 \%$ do total e $92,8 \%$ de sua população urbana é assistida quanto ao abastecimento de água com um índice de hidrometração de 92,5\%. Do total abastecido, $47 \%$ são exclusivamente por mananciais superficiais, $39 \%$ por águas subterrâneas e $14 \%$ pelos dois tipos de mananciais, conhecido como sistema misto (BRASIL, 2010).

Com a pandemia do Covid-19 e a necessidade de uma higienização constante com uso de água e sabão para a lavagem das mãos, ficou mais evidente, conforme Tucci (2008), que o planejamento urbano é realizado apenas para a "cidade formal". Para a "cidade informal", ou seja, a periferia, as favelas e as áreas griladas e de invasões, são analisadas apenas tendências dessa ocupação. Nessas áreas, muitos sequer têm torneira em casa, ficando, assim, fora dos percentuais de atendimento quanto ao abastecimento público de água.

No estado de Mato Grosso, dos 141 municípios, 61 são abastecidos por manancial superficial, 58 por subterrâneo, 20 por sistema misto e 2 sem informação (ANA, 2010). Uma das cidades desse Estado, a histórica Nossa Senhora do Livramento, teve seu surgimento em 1730 a partir da descoberta de ouro no Ribeirão dos Cocais por bandeirantes paulistas (MACIEL DA SILVA, 2016), e apesar de nascida à beira de um córrego, é e sempre foi abastecida por águas subterrâneas (SILVA; VALENTINI, 2017).

De acordo com seus moradores mais antigos, que vivem no centro do município, os córregos do local nunca foram suficientes para abastecer a população em todas as suas necessidades, visto que são intermitentes, e dessa forma, recorriam às cacimbas quando não havia o sistema de distribuição público atual (SILVA; VALENTINI, 2017). Dos nove poços tubulares perfurados ao longo do tempo, apenas quatro estão em operação e o único tratamento que as águas recebem antes da distribuição é a cloração.

A qualidade da água é definida por sua composição química, física e bacteriológica. Para o consumo humano há necessidade de uma água sem substâncias e organismos que possuam capacidade de causar efeitos fisiológicos prejudiciais ao ser humano. Os consumidores avaliam a qualidade da água potável distribuída por concessionárias de saneamento por meio das percepções sensoriais de gosto, odor e cor, e mesmo uma água que apresenta características químicas e biológicas seguras em relação à saúde, poderá ser reprovada por quem a recebe se não satisfizer esses critérios (McGUIRE, 1995).

No trabalho de Silva e Valentini (2017), que abordou o abastecimento de água antigamente e hoje no município de Nossa Senhora do Livramento, tendo como atores os moradores mais antigos do local, foram registradas insatisfações desses idosos quanto ao gosto e ao cheiro de cloro na água que chega às suas torneiras. À vista disso, o objetivo do atual trabalho foi realizar, nas residências desses moradores ou próximas a elas, medidas de alguns parâmetros físico-químicos e microbiológicos comparando seus resultados às recomendações da Portaria de Consolidação $\mathrm{n}^{\circ} 5$ do Ministério da Saúde -Anexo XX (BRAS L, 12017), de forma a verificar uma possível resposta a esta demanda.

\section{MATERIAL E MÉTODOS}

\section{ÁREA DE ESTUDO}

\section{Município de Nossa Senhora do Livramento}

Nossa Senhora do livramento faz parte da Região Metropolitana Vale do Rio Cuiabá (RMVRC), na região Centro-Sul, entre as coordenadas $15^{\circ} 46^{\prime} 30^{\prime \prime}$ Sul e $56^{\circ} 20^{\prime} 44^{\prime \prime}$ Oeste em uma área de 5.247,31 km² e altitude de 171 metros, a $32 \mathrm{Km}$ da capital do estado de Mato Grosso (SILVA; VALENTINI, 2017).

Em 1730 com a descoberta de ouro nas margens do Ribeirão dos Cocais, surgiu a primeira povoação denominada Cocais e depois São José dos Cocais. Por ali passava a estrada que ligava as minas de Cuiabá à antiga capital do Estado, Vila Bela da Santíssima Trindade, sendo, então, erguido no local um ponto de apoio às tropas. Em 1835 foi escrita a Lei Provincial que criou o Distrito de Livramento. A elevação a município se deu em 1883, e posteriormente por meio da Lei Estadual no 179, de 30 de outubro de 1948, o município teve seu nome novamente modificado para Nossa Senhora do Livramento, denominação que se faz conservada até hoje (GALVÃO, 2010).

O município limita-se ao norte, com Várzea Grande, Jangada e Rosário Oeste; ao sul, com Barão de Melgaço e Poconé; a leste, com Santo Antônio de Leverger; e a oeste, com Porto Estrela e Cáceres, pertencendo a zona fisiográfica do Pantanal (BORDEST, 2012).

De acordo com a classificação climática de Köppen, o clima é classificado como do tipo AW, tropical semiúmido, a temperatura média é de $26,5^{\circ} \mathrm{C}$, e a precipitação média anual é de $1.420 \mathrm{~mm}$ (MAITELLI, 1994).

Quanto ao relevo, é suave ondulado ou plano e a vegetação é predominantemente de Cerrado Tropical Subcaducifólio (PMSB, 2017). Os Solos em sua maioria são representados de solos rasos e de baixa fertilidade; Plintossolos e Podzólico Vermelho - Amarelo (JACOMINE et al., 1995). 
Apresentou uma população estimada de 11.609 habitantes em 2010 (IBGE, 2010), sendo 7.345 na área rural e 4.264 na área urbana. As principais atividades econômicas do Município são a pecuária, no sistema de cria, recria e corte e a agricultura de subsistência, com destaque para a produção de bananas, o que faz o povo do local ser conhecido como "papa-banana". O extrativismo mineral também é praticado no município, que possui jazidas auríferas (GALVÃO, 2010; BORDEST, 2012 MACIEL DA SILVA 2016; LIMA; MODESTO FILHO; MOURA, 2017).

Em relação aos recursos hídricos, verifica-se que os cursos d'água de maior expressão no município, pertencentes à Bacia do Alto Paraguai, são os Rios Jangada, Pari, Santana, e Bento Gomes em sua divisa territorial, além dos córregos Brumado, Sangradouro, Espinheiro, Cordeiro. Ainda, próximos à cidade, o Ribeirão Cocais, os córregos Buritizinho, João Leme e Tobatinha. Porém, por serem intermitentes e de baixa vazão, nunca garantiram o abastecimento público da cidade (SILVA; VALENTINI, 2017).

Os aquíferos encontrados no município pertencem às rochas do Grupo Cuiabá e são do tipo livre em meio fraturado. Segundo o manual de cartografia hidrogeologia (DINIZ et al., 2014) estes aquíferos possuem vazão entre 1 e $10 \mathrm{~m}^{3} / \mathrm{h}$, sendo a produtividade dos poços geralmente muito baixas, e fornecimentos contínuos dificilmente são garantidas (LIMA; MODESTO FILHO; MOURA, 2017).

O sistema de Abastecimento de Água - SAA da área urbana do município de Nossa Senhora do Livramento conta com nove poços tubulares profundos. Destes, apenas quatro encontram-se atualmente em operação, sendo que três garantem $100 \%$ do abastecimento público urbano, e um é utilizado para irrigar o campo de futebol municipal e fornecer parte da água usada pelo hospital municipal.

\section{Locais de coletas de dados}

Tabela 1. Pontos de coleta e respectivas distâncias do RAP do DAE em Nossa Senhora do Livramento-MT.

\begin{tabular}{|c|c|c|c|c|}
\hline \multirow{2}{*}{ Ponto } & \multirow{2}{*}{ Descrição } & \multicolumn{2}{|c|}{ Coordenadas } & \multirow{2}{*}{$\begin{array}{c}\text { Distância do RAP DAE } \\
(\mathrm{m})\end{array}$} \\
\hline & & W & $S$ & \\
\hline 1 & PTP 08 & $56^{\circ} 21^{\prime} 07,287^{\prime \prime}$ & $15^{\circ} 46^{\prime} 43,194^{\prime \prime}$ & 1171,11 \\
\hline 2 & RAP DAE & $56^{\circ} 20^{\prime} 48,782^{\prime \prime}$ & $15^{\circ} 46^{\prime} 18,168^{\prime \prime}$ & - \\
\hline 3 & Emanoel João & $56^{\circ} 20^{\prime} 48,951^{\prime \prime}$ & $15^{\circ} 46^{\prime} 20,752^{\prime \prime}$ & 99,37 \\
\hline 4 & Maria Gertrudes & $56^{\circ} 20^{\prime} 48,579^{\prime \prime}$ & $15^{\circ} 46^{\prime} 25,917^{\prime \prime}$ & 252,74 \\
\hline 5 & Domingos Cristiano & $56^{\circ} 20^{\prime} 52,947^{\prime \prime}$ & $15^{\circ} 46^{\prime} 22,658^{\prime \prime}$ & 261,96 \\
\hline 6 & E.E. Prof. Feliciano Galdino & $56^{\circ} 20^{\prime} 51,149^{\prime \prime}$ & $15^{\circ} 46^{\prime} 28,852^{\prime \prime}$ & 420,04 \\
\hline 7 & Alenir Maria & $56^{\circ} 20^{\prime \prime} 46,864^{\prime \prime}$ & $15^{\circ} 46^{\prime} 33,834^{\prime \prime}$ & 549,04 \\
\hline 8 & Avenida Ana Feliciana & $56^{\circ} 20^{\prime} 45,084^{\prime \prime}$ & $15^{\circ} 46^{\prime} 06,532^{\prime \prime}$ & 555,48 \\
\hline 9 & Manoel Lourenço & $56^{\circ} 20^{\prime} 50,867^{\prime \prime}$ & $15^{\circ} 46^{\prime} 33,329^{\prime \prime}$ & 584,96 \\
\hline 10 & Lourdes Neide & $56^{\circ} 20^{\prime} 19,349^{\prime \prime}$ & $15^{\circ} 46^{\prime} 18,251^{\prime \prime}$ & 611,28 \\
\hline 11 & Maria Vicência & $56^{\circ} 20^{\prime} 56,128^{\prime \prime}$ & $15^{\circ} 46^{\prime} 28,867^{\prime \prime}$ & 623,40 \\
\hline 12 & Creche Municipal & $56^{\circ} 20^{\prime} 11,793^{\prime \prime}$ & $15^{\circ} 46^{\prime} 17,539^{\prime \prime}$ & 1459,58 \\
\hline
\end{tabular}

Fonte: autores

Primeiramente foi realizada uma observação dos cavaletes das dez residências dos moradores idosos que em 2013 e 2017 haviam reclamado do gosto e do cheiro de cloro nas águas que chegavam às suas casas, de acordo com a pesquisa de Silva e Valentini (2017). Naquela ocasião, essas pessoas assinaram um Termo de Anuência Prévia, Livre e Esclarecido, aceitando participar da pesquisa, assim como ter a publicação de suas falas e imagens.

Por questões de proximidade entre alguns cavaletes dessas residências, das 10 casas optou-se por substituir três por locais próximos às mesmas e acrescentar outros que também tem uma representatividade importante em todo fluxo de água na rede: o PTP 08, por ser o poço tubular profundo de maior expressividade na distribuição de água no município, um reservatório apoiado (RAP) do Departamento de Água e Esgoto (DAE) que armazena a maior quantidade de água antes da distribuição e por ser saída para a rede, e na sequência as residências dos moradores intercaladas pela Escola Estadual Prof. Feliciano Galdino por estar no centro da cidade, uma residência na Avenida Ana Feliciana por possuir cota superior a do DAE, e a Creche Municipal, por ser final da rede, totalizando assim 12 pontos amostrados (Tabela 1). Esses pontos tiveram suas coordenadas geográficas registradas por um GPS da marca Garmin Etrex Legend $\mathrm{HCx}$ 10 de acordo com a NBR 9897 (ABNT, 1987).

\section{Metodologia}

Os parâmetros físico-químicos e microbiológicos dos 12 pontos escolhidos (Figura 1) foram avaliados em setembro de 2018, novembro de 2018 e fevereiro de 2019.

Foram selecionados nove parâmetros relevantes para a caracterização da qualidade da água, a saber: alcalinidade, cloro, cobre, dureza, ferro, $\mathrm{pH}$, turbidez, coliformes totais e Escherichia coli. 
Figura 1. Localização dos pontos de coleta na área urbana da cidade de Nossa Senhora do Livramento-MT.

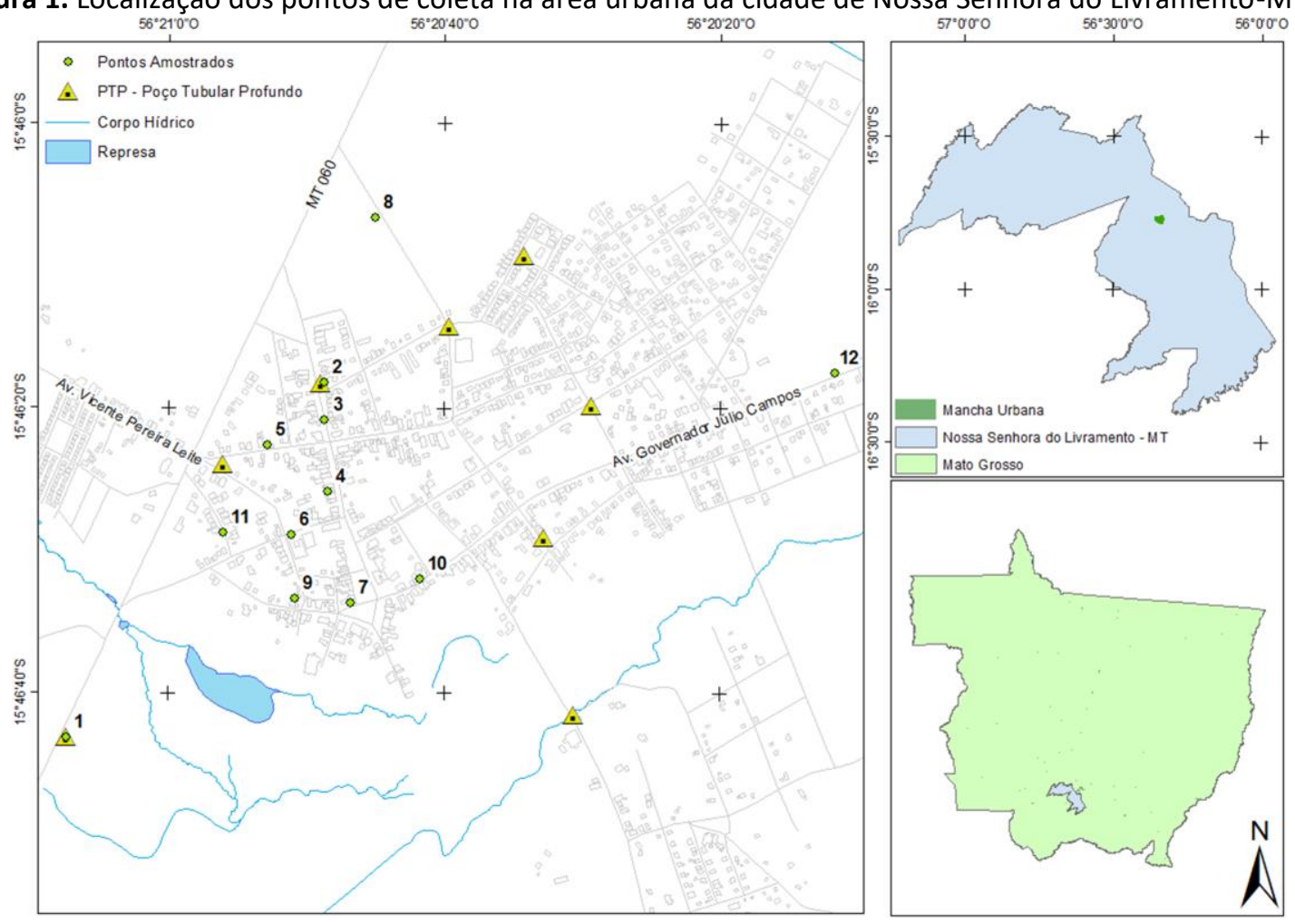

Fonte: autores

Quadro 1. Parâmetros analisados com fotômetro multiparâmetro e respectivas faixas de medição.

\begin{tabular}{cccc}
\hline Parâmetro & Faixa de Medição & Resolução & Exatidão \\
\hline Alcalinidade Total $\left(\mathrm{CaCO}_{3}\right)$ & 10 a $200 \mathrm{ppm}$ & $1 \mathrm{ppm}$ & $\pm 9 \%$ \\
Cloro livre & 0,05 a $6 \mathrm{ppm}$ & $0,01 \mathrm{ppm}$ & $\pm 3 \%$ \\
Cobre $\left(\mathrm{Cu}^{2+}\right)$ & 0,01 a $1,20 \mathrm{ppm}$ & $0,01 \mathrm{ppm}$ & $\pm 13 \%$ \\
Dureza total $\left(\mathrm{CaCO}_{3}\right)$ & 30 a $550 \mathrm{ppm}$ & $1 \mathrm{ppm}$ & $\pm 11 \%$ \\
Ferro total $\left(\mathrm{Fe}^{2+} / \mathrm{Fe}^{3+}\right)$ & 0,02 a $2,40 \mathrm{ppm}$ & $0,01 \mathrm{ppm}$ & $\pm 5 \%$ \\
$\mathrm{pH}$ & 6,4 a 8,4 & $0,1 \mathrm{ppm}$ & $\pm 0,2 \%$ \\
\hline
\end{tabular}

O mês de novembro de 2018 foi o mais completo, pois foram realizadas as oito análises propostas nos 12 pontos. Nas outras amostragens, as análises foram feitas apenas para alguns pontos e para somente alguns parâmetros físicoquímicos, que tinham uma maior relação com a queixa dos moradores em relação ao gosto da água. Ainda, para complementar, serão expostos alguns parâmetros físicoquímicos dos poços em operação no mês de setembro de 2018 para que se registrem as condições daquele momento e se possa comparar com as futuras coletas.

As medidas dos parâmetros físico-químicos alcalinidade, cloro, cobre, dureza, ferro e $\mathrm{pH}$, foram realizadas in loco com o fotômetro multiparâmetro - exact Micro 7+ (AKSO) que possui as faixas de medição apresentadas no Quadro 1. A turbidez foi medida pelo técnico da Vigilância Sanitária (Secretaria de Saúde) que usou o Turbidímetro Ap 2000 (Policontrol). As amostras de água coletadas para as análises microbiológicas foram cometidas a empresa Control Laboratório de Análise de Água e Projetos Ambientais (http://controlmt.com.br/) que utilizaram a técnica quantitativa de Membrana Filtrante estabelecida pelo Standard Methods for the Examination of Water and Wasterwater 22a Edição de 2012 (SMEWW) EPA e ABNT (quando aplicável) e o limite de confiança de 95\%.

Os resultados das análises físico-químicas e microbiológicas foram comparados ao recomendado pela Portaria de Consolidação $n^{\circ} 5$ do Ministério da Saúde, de 28 de setembro de 2017 -Anexo XX (PCR MS no 05/17), que dispõe sobre o controle e vigilância da qualidade da água para consumo humano e seu padrão de potabilidade. 0 parâmetro alcalinidade, apesar de não previsto por essa Portaria, foi medido de forma a também embasar as explicações dos parâmetros analisados, visando perceber as possíveis relações existentes entre eles. 


\section{RESULTADOS E DISCUSSÃO}

Na Portaria de Consolidação $n^{\circ} 5$ do Ministério da Saúde, de 28 de setembro de 2017 - Anexo XX (PCR MS no 05/17), estão estabelecidos os padrões microbiológicos, de turbidez, e de potabilidade para as substâncias químicas que apresentem riscos à saúde e de aceitação para o consumo humano. Gosto e odor estão enquadrados na categoria Padrão Organoléptico de Potabilidade, sendo seu valor máximo permitido (VMP) representado pela intensidade 6 , o que é uma interpretação do analista. Porém, há a seguinte observação: "Intensidade máxima de percepção para qualquer característica de gosto e odor com exceção do cloro livre, nesse caso por ser uma característica desejável em água tratada".

Em geral, a presença de gosto e odor na água potável é considerada um problema estético, não trazendo, necessariamente, riscos à saúde da população. Contudo, alguns contaminantes podem ser ao mesmo tempo, tóxicos e causarem gosto e odor (BENEDETTI; DE LUCA; CYBIS, 2009). A orientação da OMS (WHO, 2004) é que ocorrências de gosto e odor na água potável sejam investigadas, porque elas podem indicar a presença de alguma forma de poluição ou mau funcionamento das operações de tratamento e distribuição da água, podendo ser indicativo da presença potencial de compostos prejudiciais à saúde.

$O$ gosto e o odor na água potável podem ter origem no manancial de abastecimento, no tratamento e no sistema de distribuição de água potável (THOMPSON et al., 2007). No manancial a origem pode ser natural ou antropogênica e na distribuição os compostos que conferem gosto e odor a água podem ser introduzidos ou formados. Dessa forma, serão apresentadas a seguir, análises da água tanto do manancial, quanto após o tratamento e na rede de distribuição.

O munícipio de Nossa Senhora do Livramento conta com nove poços tubulares profundos, documentados, mas não outorgados, que foram perfurados paulatinamente a partir de 1973 , porém apenas quatro estão em funcionamento, o PTP 05 que irriga o campo municipal de futebol e fornece parte da água do hospital municipal, o PTP 06 que abastece o bairro Morro da Boa Vista, o PTP 08 e o novo PTP (Figura 2) que abastecem os outros setores da cidade. A necessidade de abertura de novos poços se dá pelo fato de que ao longo do tempo as vazões dos mesmos vão se tornando insuficientes como apresentado na Tabela 2. São protegidos por alambrados, sendo o acesso aos poços de responsabilidade dos funcionários do DAE (Departamento de Águas e Esgoto) do Município (SILVA; VALENTINI, 2017). Quando realizado esse trabalho ainda não havia o Novo PTP que foi aberto em 2020, a ser usado em paralelo ao PTP 08, localizado a aproximadamente 100 metros de distância deste.

É importante frisar que nessa pesquisa a ênfase será o poço tubular PTP 08, visto que este é responsável pelo abastecimento público de água de $70 \%$ da cidade de Nossa Senhora do Livramento, em especial a região central, onde foram feitas as coletas de dados. Mas, a título de comparação, na Tabela 3 são apresentados os resultados de amostras de água do PTP 06 e PTP 08 ocorrida no dia 29/9/18. O PTP 07 (Figura 3) foi declarado impróprio para uso devido ao excesso de sólidos, ferro e manganês.

Pela capacidade dissolvente da água, as águas naturais contêm muitas substâncias em solução. No ciclo hidrológico, a chuva carrega para o solo a poeira, as substâncias e os microrganismos presentes na atmosfera. Mistura-se à matéria em decomposição e outros componentes da superfície terrestre, fazendo sua viagem através das camadas do solo para formar os lençóis subterrâneos. Pelo fato de carregar gás carbônico há grande ação da água sobre as rochas calcárias (BLUMBERG; AZEVEDO NETTO, 1956). Atualizando esses autores, hoje temos muito mais substâncias para nos preocupar que são trazidas para os lençóis freáticos. Na Baixada Cuiabana, em especial no período de seca, o nível de poluentes aumenta muito, especialmente pelo crescimento das queimadas, e corrobora com essa afirmação o fato de ter se encontrado na água de um ar condicionado no município de Cuiabá, advindas do material particulado do ar atmosférico e por deriva no mesmo, a presença de nitrogênio amoniacal, sulfatos, nitratos, agrotóxicos e outras (VALENTINI et al., 2019).

Atualmente, os poços de Nossa Senhora do Livramento não são mais clorados, porém até o início de 2018 eles possuíam sistema de clorador de pastilhas (Figura 4), contudo não havia um controle efetivo da manutenção desse sistema, levando em consideração a vazão de entrada de água e o abastecimento do compartimento de cloro com as pastilhas. $O$ tempo de permanência do cloro dentro de um poço profundo é difícil de prever, porque depende de muitos fatores como a presença de substâncias reativas com o cloro que podem estar presentes na água, da temperatura, do $\mathrm{pH}$, etc. Não obstante, pela quantidade de cloro encontrada nas amostras, mesmo que dentro dos valores permitidos pela legislação, é possível que esses poços não foram rigorosamente monitorados e tiveram uma elevada cloração quando possuíam sistema clorador.

Pelo fato do ferro estar acima do limite da legislação no PTP 08, mesmo o poço tendo uma pequena dosagem de cloro, reforça a assertiva de Libânio (2016) que descreve o papel do cloro além da desinfecção nos sistemas de abastecimento. Pelo seu poder oxidativo e seu poder remanescente, também tem a função de prevenir 
Figura 2. Poços que abastecem o município de Nossa Senhora do Livramento-MT. (A) novo PTP; B: PTP 06 e C: PTP 08.

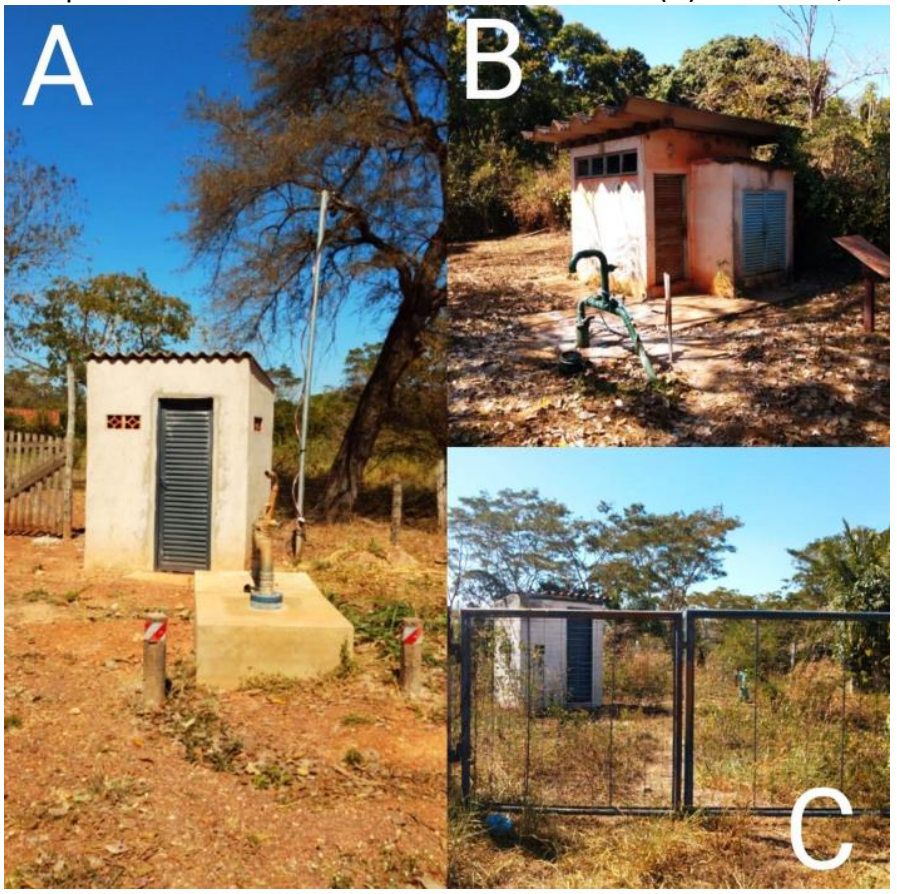

Fonte: autores

Tabela 2. Especificações dos Poços Tubulares Profundos de Nossa Senhora do Livramento-MT

\begin{tabular}{|c|c|c|c|c|c|}
\hline Endereço & $\begin{array}{l}\text { Vazão nominal } \\
\left(\mathrm{m}^{3} / \mathrm{h}\right)\end{array}$ & $\begin{array}{l}\text { Vazão atual } \\
\left(\mathrm{m}^{3} / \mathrm{h}\right)\end{array}$ & $\begin{array}{l}\text { Profundidade } \\
(\mathrm{m})\end{array}$ & $\begin{array}{c}\text { Nomenclatura } \\
\text { DAE }\end{array}$ & $\begin{array}{c}\text { Ano } \\
\text { Instalação }\end{array}$ \\
\hline $\begin{array}{l}\text { Rua Cel Botelho/Rua Benedito } \\
\text { Antunes de Almeida }\end{array}$ & 10 & 4,70 & 150 & PTP 01 & 1973 \\
\hline $\begin{array}{l}\text { Rua Ana Feliciana de Oliveira/Rua } \\
\text { Coronel Serra }\end{array}$ & 9 & 5,90 & 151 & PTP 02 & 1973 \\
\hline $\begin{array}{l}\text { Rua Carlos Antunes de Almeida/Rua } \\
\text { Vicente Pereira Leite }\end{array}$ & 8 & 4,00 & 150 & PTP 03 & 1978 \\
\hline $\begin{array}{c}\text { Rua José Mariano da Costa/Ação } \\
\text { Social }\end{array}$ & 11 & 4,30 & 159 & PTP 04 & 1987 \\
\hline $\begin{array}{l}\text { Rua Manoel Felix/Rua Lívio Mendes } \\
\text { de Freitas }\end{array}$ & 9 & 4,10 & 159 & PTP 05 & 1987 \\
\hline $\begin{array}{c}\text { Rua Adelino Metelo de Campos - } \\
\text { Bairro Morro da Boa Vista }\end{array}$ & 25 & 17,28 & 106 & PTP 06 & 1991 \\
\hline $\begin{array}{l}\text { Rua Benedito Antunes/Rua Ana } \\
\text { Feliciana }\end{array}$ & 15 & 10,80 & 125 & PTP 07 & 2002 \\
\hline $\begin{array}{l}\text { Proximidades do Córrego do } \\
\text { Ribeirão/Senhor Menino/MT } 060\end{array}$ & 42,98 & 35,00 & 104 & РTP 08 & 2008 \\
\hline $\begin{array}{l}\text { Proximidades do Córrego do } \\
\text { Ribeirão/Senhor Menino/MT } 060\end{array}$ & 35 & 35,00 & 90 & Novo PTP & 2020 \\
\hline
\end{tabular}

Fonte: DAE

crescimento de algas, controlar o sabor e o odor, remover a cor, reagindo com moléculas orgânicas e inorgânicas como nitratos, cianetos, sulfatos, ferro e manganês. Dessa maneira, é possível que quando essa quantidade de cloro for zerada nesses poços haverá problemas com o teor de ferro nos mesmos.

De acordo com Manzione (2015), o ferro ocorre geralmente associado ao manganês. Confere a água sabor amargo adstringente e coloração amarelada/turva, o que já está acontecendo com o PTP 7 (Figura 3). Ainda em seu trabalho, indica que altos teores podem estar associados a ferrobactérias ou corrosão do revestimento ou filtro do poço. 
Figura 3. Instalações do PTP 07 ao fundo do Ginásio Poliesportivo de em N. S. Livramento-MT com água amarelada e turva.

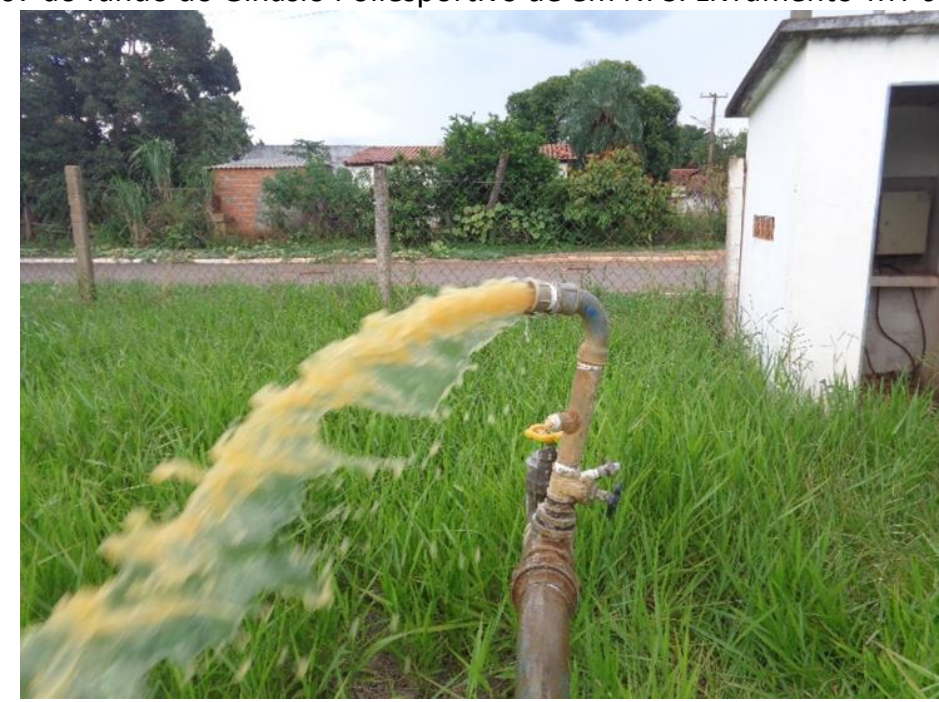

Fonte: autores

Tabela 3. Resultados das análises do dia 29/09/2018 dos poços tubulares PTP6 e PTP8 em N. S. Livramento-MT.

\begin{tabular}{lccccccc}
\hline & $\begin{array}{c}\text { Alcalinidade } \\
\mathrm{mg} / \mathrm{L}\end{array}$ & $\begin{array}{c}\text { Cloro } \\
\mathrm{mg} / \mathrm{L}\end{array}$ & $\begin{array}{c}\text { Cobre } \\
\mathrm{mg} / \mathrm{L}\end{array}$ & $\begin{array}{c}\text { Dureza } \\
\mathrm{mg} / \mathrm{L}\end{array}$ & $\begin{array}{c}\text { Ferro } \\
\mathrm{mg} / \mathrm{L}\end{array}$ & $\begin{array}{c}\mathrm{pH} \\
-\end{array}$ \\
\hline \multirow{2}{*}{ Descrição } & $\begin{array}{c}\text { VMP PCR } \\
\text { MS no } \\
\text { 05/2017 }\end{array}$ & - & $0,5 \mathrm{a} 2$ & 2 & 500 & 0,3 & - \\
\hline PTP 06 & & 177 & 0,94 & LO & HI & 0,12 & 6,8 \\
PTP 08 & 125 & 0,66 & 0,06 & 148 & 0,45 & 7,0 \\
\hline
\end{tabular}

*LO: abaixo do limite de deteç̧ão do aparelho; HI: acima do limite de detecção do aparelho.

Figura 4. Instalação do Clorador do tipo “Chupa Cabra” no PTP 08 em N. S. Livramento-MT.

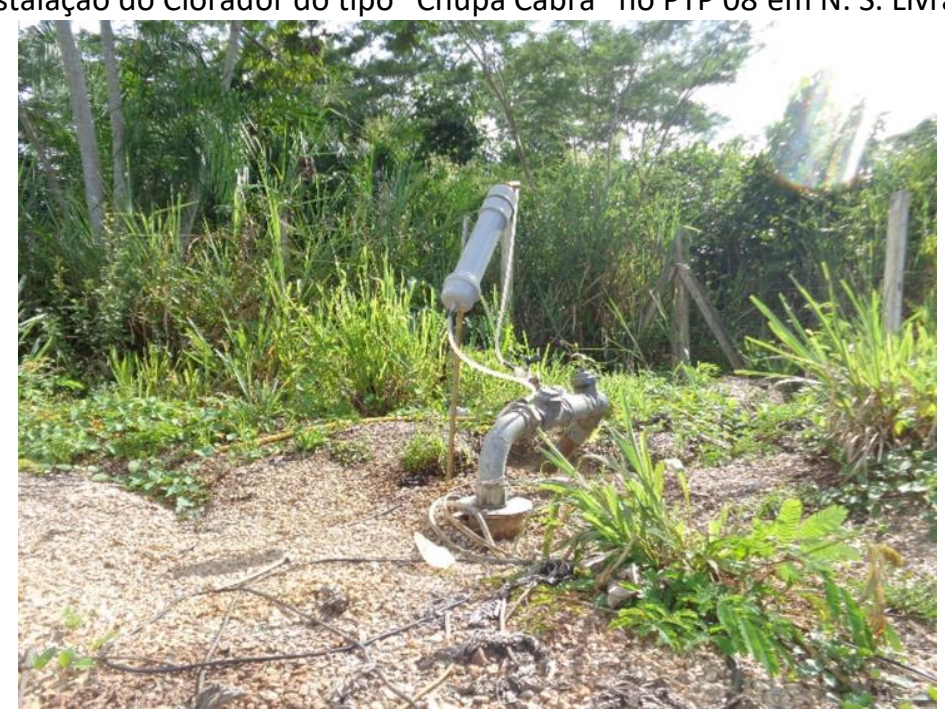

Fonte: autores

Chama a atenção os valores de $\mathrm{pH}$, dentro dos limites permitidos pela PCR 5/17, serem praticamente neutros, mesmo com alto teor de dureza provocada pelos sais de cálcio, como é o caso do PTP 06. Reforça a probabilidade de que é possível que haja nesses poços um alto teor de sais de ferro com características ácidas de forma a neutralizar a alcalinidade desses sais de cálcio.

A adutora principal, encarregada pelo encaminhamento da água do PTP 08 até os reservatórios instalados na sede do $\mathrm{DAE}$, possui o comprimento total de 1.200 metros em material do tipo aço galvanizado e PVC DEFOFO, sendo que o primeiro possui apenas 40 metros e ambos com diâmetro de 
$100 \mathrm{~mm}$. Ela não possui nenhum tipo de registro de manobra e/ou registro auxiliar de proteção no encaminhamento da tubulação (SILVA; VALENTINI, 2017). Atualmente a adutora foi interligada por um " $\mathrm{T}$ " junto a tubulação adutora do Novo PTP para suprir as atuais necessidades do DAE.

O tratamento da água advinda do PTP 08 no DAE é realizado por simples desinfecção com o uso de hipoclorito de cálcio granulado 65\%, cuja dosagem é executada de forma manual, uma vez ao dia, durante o enchimento dos reservatórios 1 e 2. Segundo Meyer (1994), os desinfetantes químicos necessitam ser uniformemente dispersos na água, para garantir uma concentração uniforme; portanto, a ausência de agitação desfavorece a sua total diluição na água. O teor de $\mathrm{Ca}(\mathrm{ClO})_{2}$ em cloro ativo de 65 a $70 \%$ apresenta uma estabilidade muito boa ao longo do tempo para impedir a ação bacteriana (GICQUEL et al., 2007).

O cloro aplicado sob a forma de hipoclorito de cálcio, em contato com a água, se ioniza conforme as reações:

$$
\begin{aligned}
& \mathrm{Ca}(\mathrm{ClO})_{2}+2 \mathrm{H}_{2} \mathrm{O} \leftrightarrow 2 \mathrm{HOCl}+\mathrm{Ca}^{2+}+2 \mathrm{OH}^{-} \\
& \mathrm{HOCl} \leftrightarrow \mathrm{OCl}^{-}+\mathrm{H}^{+}
\end{aligned}
$$

Na reação do produto que contém cloro com a água, há formação do ácido hipocloroso ( $\mathrm{HOCl})$ que é o agente desinfetante. Esse ácido hipocloroso formado, dependendo do $\mathrm{pH}$ da água, se dissocia formando íon hipoclorito ( $\left.\mathrm{OCl}^{-}\right)$. A extensão dessa dissociação está ligada ao valor do pH. Em $\mathrm{pH}$ ácido há maior formação de ácido hipocloroso e em pH alcalino acima de 7,5 há maior formação de íon hipoclorito. O cloro presente na água na forma de ácido hipocloroso e de íon hipoclorito é denominado de cloro residual livre. É importante ressaltar que o ácido hipocloroso é um desinfetante mais potente do que o íon hipoclorito, sob as mesmas condições de tempo, de contato, e de dosagem, mas que este estará em maior concentração se o pH da água for menor que 7 (MEYER, 1994; BRASIL, 2014).

Posteriormente, a água clorada é bombeada para dois reservatórios com capacidade de 396 e $420 \mathrm{~m}^{3}$ de armazenamento, respectivamente chamados de RAP 1 e RAP 2 que são interligados. Os dados coletados nesse trabalho referem-se ao RAP 2. No DAE são medidos apenas o pH e teor de cloro e as demais análises são feitas por empresas terceirizadas (SILVA; VALENTINI, 2017). A Secretaria de Saúde, por meio da Vigilância Sanitária, também faz análises mensais na rede, contudo são pontos aleatórios e os resultados não são para atendimento ao $\mathrm{DAE}$, e sim para alimentar o Sistema de Informação de Vigilância da Qualidade da Água para Consumo Humano do Departamento de Informática do Sistema Único de Saúde (DATASUS).

Atualmente, na rede de água são distribuídos, em média, 700.000 litros por dia para a população. As adutoras que saem do reservatório para a rede possuem diâmetro de $200 \mathrm{~mm}, 150 \mathrm{~mm}, 100 \mathrm{~mm}$ e $75 \mathrm{~mm}$ sendo as redes primárias, e $50 \mathrm{~mm}$ as redes secundárias, ambas em material tipo PVC DEFOFO. Embora não possua macro medidores instalados no sistema, o índice de perdas na distribuição é da ordem de $43,95 \%$, conforme relatórios do sistema comercial do DAE (LIMA; MODESTO FILHO; MOURA, 2017).

Antes de fazer todos os pontos com todos os parâmetros propostos, foram realizadas algumas incursões com o parâmetro de mais enfoque do trabalho, que é o cloro, em datas que serão apresentadas a seguir. No dia 14/09/18, foram coletadas amostras em oito pontos na perspectiva das residências dos moradores que outrora reclamaram do gosto do cloro na água que chegava às suas torneiras, além da Creche Municipal, por ser final da rede (Tabela 4).

Além do teor de cloro, também foi medida a turbidez nos cavaletes dessas casas, visto que é um parâmetro que mede

\begin{tabular}{|c|c|c|c|c|}
\hline & & & $\begin{array}{l}\text { Cloro } \\
\mathrm{mg} / \mathrm{L}\end{array}$ & $\begin{array}{c}\text { Turbidez } \\
\text { UT }\end{array}$ \\
\hline Ponto & Descrição & $\begin{array}{c}\text { VMP PCR MS } \\
\text { no 05/2017 }\end{array}$ & 0,5 a 2 & 5 \\
\hline 3 & Emanoel João & & 0,34 & 4,55 \\
\hline 4 & Maria Gertrudes & & 0,36 & 3,58 \\
\hline 5 & Domingos Cristiano & & 0,39 & 4 \\
\hline 7 & Alenir Maria & & 0,31 & 16 \\
\hline 9 & Manoel Lourenço & & 0,27 & 6,04 \\
\hline 10 & Lourdes Neide & & 0,28 & 0,75 \\
\hline 11 & Maria Vicência & & 0,33 & 3,62 \\
\hline 12 & Creche Municipal & & 0,48 & 2,37 \\
\hline
\end{tabular}

Tabela 4. Resultados das análises de água do dia 14/08/2018 em N.S. Livramento-MT. 
a matéria em suspensão, tais como argilas, silte e partículas orgânicas coloidais, e pelo motivo de que para ser removida necessitaria do processo de coagulação. Poderia representar um perigo de contaminação biológica pela razão dos patógenos poderem estar adsorvidos no sólido em suspensão, caso o teor de cloro na rede não estivesse dentro do que preconiza a legislação. Mas, só o fato da turbidez ser percebida a olho nu causa um incômodo e rejeição pelo próprio padrão estético.

Conforme a Portaria de Consolidação MS no 05/17, Anexo XX, a concentração de cloro ativo deve estar entre 0,5 e $2 \mathrm{mg} / \mathrm{L}$, com um número não menor que $0,2 \mathrm{mg} / \mathrm{L}$ para ser considerada clorada. Dessa forma, na rede, apesar de abaixo de $0,5 \mathrm{mg} / \mathrm{L}$, ainda há um residual maior que $0,2 \mathrm{mg} / \mathrm{L}$, que garantiria a potabilidade da água nos pontos avaliados.

Porém, a turbidez não foi aceitável em dois dos oito pontos analisados, sendo que no ponto 7 estava praticamente o triplo do que recomenda a legislação e o ponto 9 com turbidez 6,04 . Uma possível explicação para esse fato é que dos pontos analisados, o ponto 7 é o mais baixo da rede em relação ao DAE e em seguida o ponto 9 . Vale ressaltar que esses dois pontos têm tubulação de $100 \mathrm{~mm}$ e $50 \mathrm{~mm}, 1$ curva, 2 cruzetas e 2 T. Tanto a cota altimétrica menor, quanto essas variações nas tubulações podem contribuir para um acúmulo de material em suspensão na rede nesses locais. Cabe ainda salientar, que a rede de abastecimento, em sua totalidade, não possui válvula de descarga de água no final de rede para que seja realizada a descarga de água e sólidos acumulados.

No dia 27/9/18 foi realizada uma nova rodada de coletas, também em oito pontos, agora pegando tanto a água do poço tubular in natura, como após a cloração no RAP 2, em algumas casas dos moradores já mencionados, na Escola Estadual e na Creche municipal. Foi incluído um parâmetro a mais em relação a amostragem anterior, o pH (Tabela 5).

Os resultados de $\mathrm{pH}$ foram de 6,8 a 7,6. A presença de ferro e manganês poderá afetar no processo de cloração, contribuindo para a oxidação do metal, tornando-os insolúveis na água.

Novamente observou-se que o PTP 08, mesmo não sendo mais clorado, com um residual de cloro livre dentro do previsto pela legislação. O curioso, porém, é que após receber a cloração no $\mathrm{DAE}$, no próprio reservatório apoiado antes da distribuição para a rede, o teor de cloro foi menor do que na água bruta. Cabe observar que a cloração é realizada para atender os valores mínimos ou insuficientes de cloro. Na rede, com média de 0,56 $\pm 011 \mathrm{mg} / \mathrm{L}$, foi sofrendo variações, não apenas como esperado com o decaimento do teor de cloro à medida que foi aumentando a distância na rede em relação ao RAP do DAE. Vieira et al. (2004) apontaram fatores que também reduzem o cloro livre presente na água, como o tempo de detenção em reservatórios, quantidade de pontos de ramificação de redes e velocidade de escoamento. Somados a esses, as variações podem estar associadas a essas mudanças de trajetórias na rede e as conexões a elas associadas, como também a cota altimétrica. Os pontos de coleta e os respectivos diâmetros da tubulação de água na rede são apresentados na Figura 5.

Essas informações são importantes pelo fato de que, uma vez formados, os bicarbonatos, comuns em águas subterrâneas, principalmente os de cálcio, são transportados pela água nas tubulações e são susceptíveis a serem depositados nas paredes das instalações. Essas incrustações são formadas em pontos com mudança de direção da canalização, nos quais o fluxo se torna turbulento pelos obstáculos e válvulas, e em pontos de saída, pois a queda brusca de pressão ocasiona o acúmulo de cristais de cálcio, cuja estrutura adere e se deposita em qualquer lugar. Esses depósitos podem ocasionar níveis de estrangulamento de seções de tubos de PVC rígido, resultando até na obstrução total da tubulação (VIEIRA, 2016).

$\mathrm{O}$ pH é um parâmetro utilizado para expressar a

Tabela 5. Resultados das análises de água do dia 27/09/2018 em N.S. Livramento-MT.

\begin{tabular}{|c|c|c|c|c|c|}
\hline & & & $\begin{array}{l}\text { Cloro } \\
\mathrm{mg} / \mathrm{L}\end{array}$ & $\begin{array}{c}\mathrm{pH} \\
- \\
\end{array}$ & $\begin{array}{c}\text { Turbidez } \\
\text { UT }\end{array}$ \\
\hline Ponto & Descrição & $\begin{array}{c}\text { VMP PCR MS } \\
\text { n } 05 / 2017\end{array}$ & 0,5 a 2 & - & 5 \\
\hline 1 & PTP 08 & & 0,79 & 6,8 & 3,95 \\
\hline 2 & RAP DAE & & 0,54 & 7,1 & 6,7 \\
\hline 4 & Maria Gertrudes & & 0,49 & 7,2 & 5,08 \\
\hline 6 & E.E. Prof. Feliciano Galdino & & 0,58 & 7,3 & 2,87 \\
\hline 7 & Alenir Maria & & 0,79 & 7,6 & 7,6 \\
\hline 10 & Lourdes Neide & & 0,37 & 7,3 & 2,75 \\
\hline 11 & Maria Vicência & & 0,65 & 7,2 & 3,25 \\
\hline 12 & Creche Municipal & & 0,48 & 7,2 & 2,37 \\
\hline
\end{tabular}


alcalinidade ou a acidez de uma amostra e pode fornecer indícios do grau de poluição em um ecossistema aquático quando analisado junto com outras variáveis (GARCIA; VALENTINI; FARIA, 2015). De acordo com a PCR MS no 05/2017, o pH da água deve ser mantido na faixa de 6,0 a 9,5 na rede de distribuição. Consoante a Manzione (2015), o pH do meio controla as reações químicas e degradação de muitos poluentes.

A média do $\mathrm{pH}$ na rede nessa data de coleta foi de 7,3 $\pm 0,1$, o que numericamente atende a legislação e pode ser interpretado como uma água quase neutra. Há muito pouca variação do valor de $\mathrm{pH}$ na rede, exceto para o ponto 7 , menor cota altimétrica, onde há também uma maior turbidez e maior concentração de cloro. É possível que este ponto sofra um acúmulo de material em suspensão, depósito de bicarbonatos, o que poderia explicar esse aumento do $\mathrm{pH}$.

Interessante também que a turbidez no DAE estava acima do permitido pela legislação, sendo maior que da água bruta (PTP 08). Isso pode ser um indício que o RAP 2 tinha acúmulo de material em suspensão, necessitando de limpeza. O valor máximo para turbidez deve ser de 1,0 UT (unidade turbidimétrica) para água subterrânea desinfectada e 5,0 UT como padrão de aceitação para o consumo humano (PALUDO, 2010), ou seja, o PTP 08, também estava com a turbidez acima do que preconiza a legislação.

No dia $12 / 11 / 18$, foi realizada uma nova coleta abrangendo os 12 pontos selecionados, com oito parâmetros físico-químicos e microbiológicos apresentados na Tabela 6 .

$\mathrm{O} \mathrm{pH}$ estava ligeiramente alcalino antes da entrada na rede (ponto 2) e na rede permaneceu praticamente neutro, com exceção dos pontos 7 e 12. Como já discutido, até pela diminuição da velocidade de escoamento no Ponto 7 (menor cota altimétrica), e pelo ponto 12 (final da rede) receber todo acúmulo da rede, são locais propícios ao acúmulo de sólidos, substâncias que pelo $\mathrm{pH}$ indicam ser alcalinas. Piveli (2001) aguça a importância do pH nas análises de águas, observando que dependendo de sua variação, ou seja, da concentração de íons hidrônios em solução, pode-se ter maior solubilidade de algumas substâncias como a precipitação de outras. Corrobora ainda, o fato da dureza, que é um parâmetro que indica a presença de sais de cálcio e magnésio, apresentar nesses pontos valores maiores do que o ponto 2 (RAP).

Pelo fato de tratar-se de água subterrânea a dureza é um parâmetro importante. O Cálcio $\left(\mathrm{Ca}^{2+}\right)$ é o elemento mais abundante na maioria das águas subterrâneas. $\mathrm{O}$ magnésio $\left(\mathrm{Mg}^{2+}\right)$ apresenta propriedades semelhantes ao cálcio, porém é mais solúvel e tem maior dificuldade de precipitar (CUSTODIO; LLAMAS, 1983). São quatro os principais compostos que conferem dureza às águas: bicarbonato de cálcio, bicarbonato de magnésio, sulfato de cálcio e sulfato de magnésio (PIVELI, 2001).

Ainda amparando essa linha de discussão, temos a alcalinidade, cujos componentes principais são os sais do ácido carbônico, ou seja, bicarbonatos e carbonatos, e os hidróxidos. Piveli (2001) aponta que a alcalinidade não se constitui em padrão de potabilidade, ficando este efeito limitado pelo valor do $\mathrm{pH}$, e pelo fato das amostras terem $\mathrm{pH}$ menor que 8,3 indica que nessas a alcalinidade total é devida somente ao bicarbonato. A alcalinidade das águas não representa risco potencial à saúde pública. Provoca alteração no paladar e a rejeição da água em concentrações inferiores àquelas que eventualmente pudessem trazer

Figura 5. Distribuição dos pontos de coleta e respectivos diâmetros da tubulação de água em N.S. Livramento-MT. $56^{\circ} 21^{\circ} 0^{\circ} \mathrm{O}$ $56^{\circ} 20^{\circ} 40^{\circ} \mathrm{O}$ (6.20

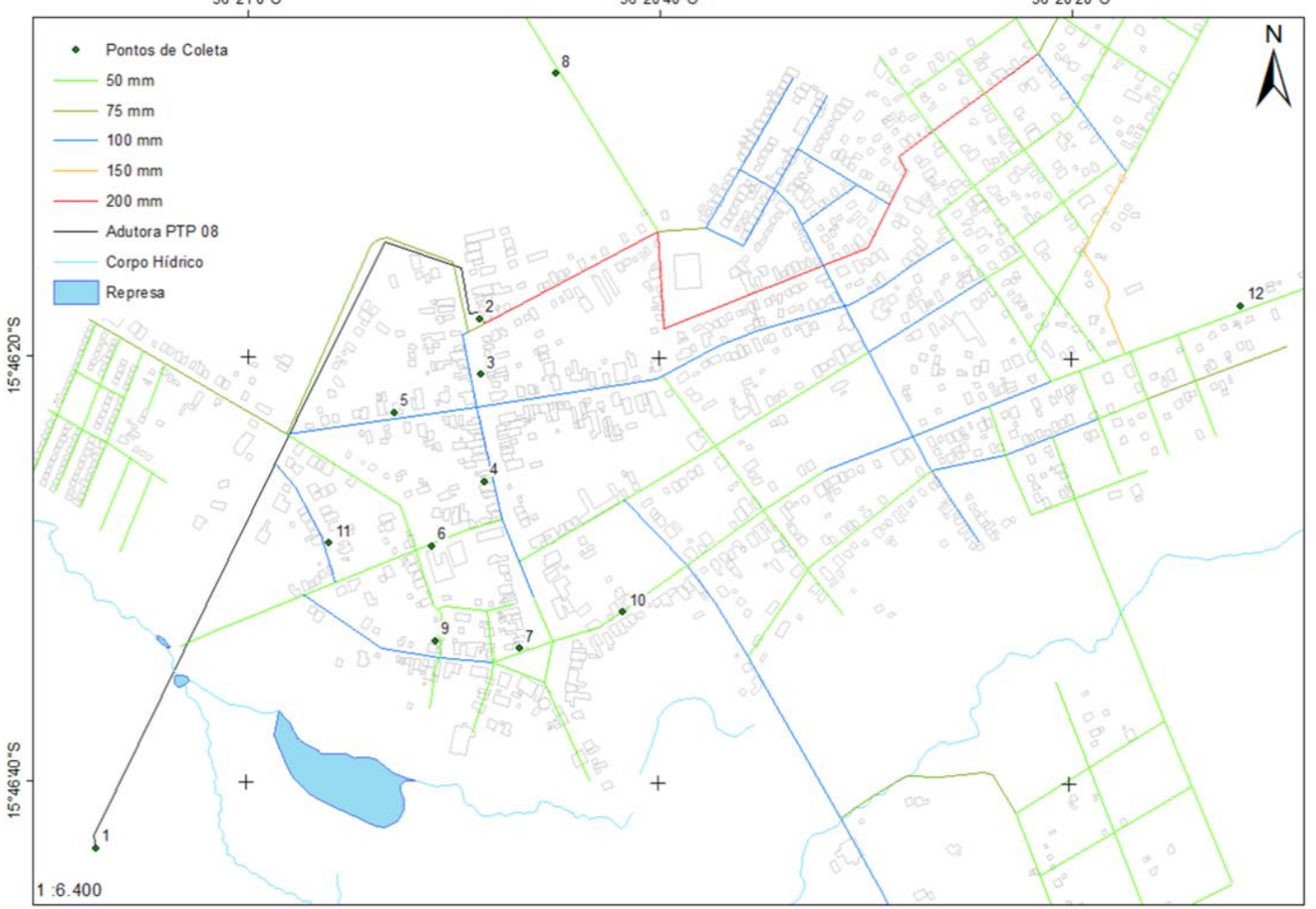


prejuízos mais sérios.

Blumber e Azevedo Netto (1956) apontaram a relação entre a alcalinidade e dureza na água. A alcalinidade é devida somente a bicarbonatos de cálcio e magnésio, de forma que a alcalinidade nesse caso é igual a dureza, tendo em vista que a dureza é decorrente de sais desses metais. No entanto, quando os bicarbonatos de sódio e potássio contribuem para a alcalinidade sem influenciar na dureza, nesse caso a alcalinidade excederá a dureza. Os resultados da Tabela 6 corroboram essa assertiva, visto que, como a alcalinidade excede o valor da dureza em muitos pontos, na água de abastecimento deve ocorrer também a presença bicarbonatos de sódio e potássio.

O ferro e o cobre estão dentro do limite de aceitação pela legislação. A avaliação do ferro nas águas subterrâneas utilizadas para consumo humano se deve à sua propriedade organoléptica, ou seja, possui propriedades que atuam sobre os sentidos e/ou órgãos (CUSTODIO; LLAMAS, 1983). O ferro pode estar presente em baixas concentrações na maioria das águas e normalmente está associado ao manganês, ocorrendo em diversas formas químicas. Nas águas profundas no estado de bicarbonato ferroso, $\mathrm{Fe}\left(\mathrm{HCO}_{3}\right)_{2}$, é solúvel na ausência de oxigênio, porém na presença deste é oxidado a hidróxido férrico, $\mathrm{Fe}(\mathrm{OH})_{3}$, altamente insolúvel dando a água um aspecto avermelhado e turvo (BLUMBERG; AZEVEDO NETTO, 1956). No local, o ferro pode estar
O PTP 08 (ponto 1) ainda apresentou a presença de cloro. O cloro teve uma variação decrescente em relação ao RAP (ponto 2), todavia não na ordem sequencial da rede. Esses fatores já foram discutidos anteriormente, mas vale reforçar o ponto 7. É significativo aludir, de acordo com a OPAS (1999), que no processo de demanda de cloro, quando este é adicionado à água, ao exercer sua ação oxidante, reage com substâncias inorgânicas e orgânicas combinando-se com compostos nitrogenados, produzindo subprodutos clorados chamados de cloro residual combinado, as cloraminas. Enquanto esses compostos não forem totalmente destruídos, não ocorrerá desinfecção e o cloro residual será nulo. Posteriormente, o cloro oxida as cloraminas reduzindo o teor de cloro combinado, e quando essa oxidação se completa eleva-se a quantidade de cloro residual livre, mais eficaz como desinfetante. Isso significa que a presença desses materiais oxidáveis na água irá consumir parte da quantidade de desinfetante necessária para destruir os organismos (DEGRÉMONT, 1979).

Esse processo oxidativo do cloro pode ser influenciado por fatores físicos e químicos, tais como temperatura, $\mathrm{pH}$, velocidade de escoamento e concentração de substâncias reativas ao cloro, e dos elementos do sistema de distribuição, como o diâmetro da tubulação, o material, a idade do sistema, entre outros (CLARK; ROSSMAN; WYNER, 1995).

Tabela 6. Resultados das análises de água do dia 12/11/2018 em N.S. Livramento-MT.

\begin{tabular}{|c|c|c|c|c|c|c|c|c|c|c|}
\hline & & & $\begin{array}{c}\text { Alcalinidade } \\
\mathrm{mg} / \mathrm{L}\end{array}$ & $\begin{array}{l}\text { Cloro } \\
\mathrm{mg} / \mathrm{L}\end{array}$ & $\begin{array}{l}\text { Cobre } \\
\mathrm{mg} / \mathrm{L}\end{array}$ & $\begin{array}{c}\text { Dureza } \\
\mathrm{mg} / \mathrm{L}\end{array}$ & $\begin{array}{l}\text { Ferro } \\
\mathrm{mg} / \mathrm{L}\end{array}$ & $\begin{array}{c}\mathrm{pH} \\
-\end{array}$ & $\begin{array}{c}\text { Coliformes } \\
\text { totais } \\
\text { UFC/100mL }\end{array}$ & $\begin{array}{c}\text { E. Coli } \\
\text { UFC } / 100 \mathrm{~mL}\end{array}$ \\
\hline Ponto & Descrição & $\begin{array}{c}\text { VMP } \\
\text { PCR MS } \\
\text { no } \\
05 / 2017\end{array}$ & - & 0,5 a 2 & 2 & 500 & 0,3 & - & Ausentes & Ausentes \\
\hline 1 & PTP 08 & & $\mathrm{HI}$ & 0,62 & 0,05 & 182 & LO & 6,8 & $<1$ & $<1$ \\
\hline 2 & RAP DAE & & 131 & 1,09 & 0,11 & 72 & LO & 7,3 & $<1$ & $<1$ \\
\hline 3 & Emanoel João & & 133 & 0,98 & 0,2 & $\mathrm{HI}$ & LO & 7,0 & $<1$ & $<1$ \\
\hline 4 & Maria Gertrudes & & 131 & 0,87 & LO & 73 & LO & 7,0 & $<1$ & $<1$ \\
\hline 5 & Domingos Cristiano & & 135 & 0,69 & LO & 155 & LO & 7,0 & $<1$ & $<1$ \\
\hline 6 & E.E. Prof. Feliciano Galdin & & 131 & 0,76 & LO & 88 & LO & 7,0 & $<1$ & $<1$ \\
\hline 7 & Alenir Maria & & 124 & 0,83 & LO & 135 & LO & 7,2 & $<1$ & $<1$ \\
\hline 8 & Avenida Ana Feliciana & & 135 & 0,75 & LO & 75 & LO & 7,0 & $<1$ & $<1$ \\
\hline 9 & Manoel Lourenço & & 132 & 0,76 & 0,08 & 132 & LO & 7,0 & $<1$ & $<1$ \\
\hline 10 & Lourdes Neide & & 140 & 0,61 & LO & 134 & LO & 7,0 & $<1$ & $<1$ \\
\hline 11 & Maria Vicência & & 133 & 0,79 & 0,05 & 80 & LO & 7,0 & $<1$ & $<1$ \\
\hline 12 & Creche Municipal & & 130 & 0,7 & 0,03 & 128 & LO & 7,5 & $<1$ & $<1$ \\
\hline
\end{tabular}

*LO: abaixo do limite de detecção do aparelho; HI: acima do limite de detecção do aparelho.

associado principalmente ao solo laterítico do Grupo Cuiabá e da ocorrência de piritas disseminadas tanto nos filitos como nos metadiamictitos (APOITIA et al., 2004).
A desinfecção, desta forma, é operação unitária obrigatória, pois somente ela inativa qualquer tipo de microrganismo patogênico existente e previne o crescimento 
microbiológico nas redes de distribuição (BRASIL, 2014).

Em relação a queixa dos moradores, analisando da captação, tratamento, reservação e distribuição de água na rede, primeiramente pode-se pensar nos produtos metabólitos de microrganismos e decomposição de matéria orgânica presentes em mananciais de abastecimento que também são fontes comuns de compostos causadores de gosto e odor na água potável. No hipolímnio de reservatórios e em águas subterrâneas onde prevalecem condições anaeróbias, bactérias obtêm energia em reações de redução de sulfatos $\left(\mathrm{SO}_{4}{ }^{2-}\right)$ a sulfeto de hidrogênio $\left(\mathrm{H}_{2} \mathrm{~S}\right)$, composto que confere gosto de ovo podre à água. $\mathrm{O}$ ambiente redutor também favorece a ocorrência das formas reduzidas (solúveis) de ferro, manganês e nitrogênio (amônia), as quais também contribuem para a ocorrência de gosto e odor na água (BENEDETTI; DE LUCA; CYBIS, 2009).

Em relação a desinfecção, o cloro e as cloroaminas possuem a capacidade de remover certos compostos que causam gosto e odor, mas, ao mesmo tempo, podem produzir subprodutos por reações com a matéria orgânica de águas de abastecimento formando, por exemplo, aldeídos, clorofenóis e trihalometanos. Muitos destes subprodutos são odorantes, como o iodofórmio e o bromofórmio, ambos com odores característicos medicinais. Além disso, são ineficientes na remoção de compostos causadores de odores de terra e mofo, como 2-metilisoborneol e geosmina (BENEDETTI; DE LUCA; CYBIS, 2009). Vale lembrar o episódio do início do ano de 2020 em que moradores do Rio de Janeiro reclamaram do cheiro e da cor da água tratada e distribuída pela Companhia Estadual de Águas e Esgotos do Rio de Janeiro - CEDAE. Alguns confirmaram ter tido ardência nos olhos e náuseas após o consumo. Entretanto, apesar de conferir odor e sabor em intensidade, que causa objeção ao consumo humano, a geosmina não é tóxica, mas, potentes (cianotoxinas), que precisam ser removidas durante o tratamento da água para não comprometer a saúde da população (FONSECA et al., 2020).

O padrão microbiológico traz a obrigatoriedade da análise de E.coli, considerado o melhor indicador bacteriano para contaminação fecal (FERNANDES; GOIS, 2015). As análises de todos os pontos se mostraram dentro do padrão, ou seja, indicando a ausência de microrganismos patogênicos desde o poço PTP 08 até o final da rede.

No dia 22/02/19, foi amostrado em quatro pontos, sendo o PTP 08, o RAP 2, uma das casas e na creche, final da rede, quatro parâmetros mostrados na Tabela 7.

Os resultados se mantiveram dentro do que foi discutido nas coletas das datas anteriores, em que o PTP 08 ainda apresentou cloro residual, a alcalinidade sem variações expressivas, o pH próximo ao neutro e novamente no ponto 12 , final da rede, um $\mathrm{pH}$ ligeiramente alcalino e uma maior alcalinidade pelo acúmulo de sólidos e substâncias recebidas de todo trajeto do fluxo da água.

A exemplo de Burlingame e Anselme (1995) deve-se olhar a rede de distribuição de água como um reator no qual processos físicos, químicos e biológicos ocorrem, com reflexos na qualidade da água. Corrosão, formação de biofilmes, deterioração de revestimentos internos, reservação da água e permeabilidade das canalizações à difusão de contaminantes externos são processos pelos quais a qualidade da água pode ser alterada.

A melhor forma de se evitar esses problemas é o monitoramento regular da qualidade da água para alertar com antecedência sobre o surgimento de condições propicias para o desenvolvimento de gosto e odor até porque a rejeição à água potável apresenta um efeito indireto sobre a saúde, pois os indivíduos podem reduzir a quantidade ingerida a um valor menor do que o necessário

Tabela 7. Resultados das análises de água do dia 22/02/2019 em N.S. Livramento-MT.

\begin{tabular}{|c|c|c|c|c|c|c|}
\hline & & & $\begin{array}{c}\text { Alcalinidade } \\
\mathrm{mg} / \mathrm{L}\end{array}$ & $\begin{array}{l}\text { Cloro } \\
\mathrm{mg} / \mathrm{L}\end{array}$ & $\begin{array}{c}\text { Cobre } \\
\mathrm{mg} / \mathrm{L}\end{array}$ & $\begin{array}{c}\mathrm{pH} \\
-\end{array}$ \\
\hline Ponto & Descrição & $\begin{array}{c}\text { VMP PCR MS } \\
\text { no 05/2017 }\end{array}$ & - & 0,5 a 2 & 2 & - \\
\hline 1 & PTP 08 & & 164 & 0,82 & LO & 6,8 \\
\hline 2 & RAP DAE & & 127 & 0,88 & LO & 7,1 \\
\hline 10 & Lourdes Neide & & 139 & 0,86 & 0,08 & 7,3 \\
\hline 12 & Creche Municipal & & 149 & 0,73 & 0,12 & 7,6 \\
\hline
\end{tabular}

*LO: abaixo do limite de detecção do aparelho.

pode indicar a presença de cianobactérias em grande quantidade na água captada para o tratamento. Esses microrganismos podem produzir algumas toxinas muito para a satisfação das suas necessidades fisiológicas (BENEDETTI; DE LUCA; CYBIS, 2009).

A percepção humana sobre o sabor e o odor constitui 
parâmetro de controle da qualidade da água distribuída, visando, exclusivamente, a não rejeição do consumidor. Não há necessariamente risco sanitário associado, exclusivamente, ao sabor e ao odor da água (FONSECA et al., 2020). Por parte do DAE do município de Nossa Senhora do Livramento, seria importante a instalação de filtros de carvão ativado após a etapa de cloração, mas, enquanto isso não ocorre, a adoção de filtro de barro antes do consumo da água seria uma medida interessante para esses moradores envolvidos na presente pesquisa, pelo fato de que os filtros realizam a adsorção de muitos compostos causadores de gosto e odor na água.

O Marco Legal do Saneamento Básico (Lei no 14.026, de 2020) prevê universalizar o saneamento básico no país até 31 de dezembro de 2033, com a meta de atingir a cobertura de $99 \%$ para o fornecimento de água potável e de $90 \%$ para a coleta e tratamento de esgotos. Os municípios ou estados terão que fazer uma concorrência aberta a empresas privadas, por meio de licitação, e as interessadas terão que se comprometer com a meta de universalização dos serviços. É importante pensar que essas metas incluam tanto a "cidade formal" quanto a "cidade informal", e que prevejam não só uma melhora no tratamento de água, mas também um monitoramento mais amplo e constante das substâncias e microrganismos na rede de distribuição enquanto medidas de prevenção de saúde da população.

\section{CONCLUSÕES}

- A percepção humana sobre o sabor e odor constitui parâmetro de controle da qualidade da água distribuída e deve ser investigado todas as vezes em que houver reclamação por parte dos consumidores;

- Os resultados do teor de cloro na rede estão dentro do que preconiza a legislação e asseguram a qualidade da água em relação aos microrganismos patogênicos;

- É necessária uma melhor atenção quanto à dosagem e diluição do cloro no RAP/DAE para que não haja muitas variações na rede de distribuição;

- É possível que haja problemas de compostos de ferro e manganês insolúveis nas águas da rede de distribuição, caso o cloro não seja mais bem administrado;

- É necessária a instalação de filtro do tipo carvão ativado para a remoção do ferro e manganês da água dos reservatórios do DAE na etapa posterior a simples desinfecção;

- A adoção do uso de filtro de barro nas casas dos moradores poderia melhorar o gosto da água em relação ao cloro.

\section{AGRADECIMENTOS}

Agradecemos aos moradores idosos do centro de Nossa Senhora do Livramento-MT, que nos motivaram a fazer essa pesquisa, a parceria da Control - Laboratório de Análises de Água e Projetos Ambientais, na pessoa do Engenheiro Sanitarista e Ambiental Gian Pietro Benevento, pela execução das análises microbiológicas e à Vigilância Sanitária, na pessoa do Fiscal Valdir da Costa pelas medidas de turbidez desse trabalho.

\section{REFERÊNCIAS}

APOITIA, L. F. M.; ROSA FILHO, E. F.; BITTTENCOURT, A. V. L.; HINDY, E. Caracterização preliminar da qualidade das águas subterrâneas na cidade de Cuiabá-MT. Boletim Paranaense de Geociências, n. 54, p. 7-17, 2004.

ASSOCIAÇÃO BRASILEIRA DE NORMAS TÉCNICAS. NBR 16098: ABNT, 2012. Aparelho para melhoria da qualidade da água para consumo humano - Requisitos e métodos de ensaio.

ASSOCIAÇÃO BRASILEIRA DE NORMAS TÉCNICAS. NBR 9897: planejamento de amostragem de efluentes líquidos e corpos receptores - procedimento. Rio de Janeiro, 1987.

BENETTI, A. D.; DE LUCA, S. J.; CYBIS, L. F. Remoção de Gosto e Odor em Processos de Tratamento de Água. In: Desenvolvimento e otimização de tecnologias de tratamento de águas para abastecimento público, que estejam poluídas com microrganismos, toxinas e microcontaminantes. Pádua, V. L. (coord) Programa de Pesquisas em Saneamento Básico - PROSAB - Edital 05, Rio de Janeiro: ABES, 2009. p.292-360.

BLUMBERG, E.; AZEVEDO NETTO, J. M. Alcalinidade e dureza das águas naturais: processos de redução da dureza. Revista DAE, v.28, n.1033, p.63-79, 1956.

BORDEST, S. M. L. Peculiaridades da cultura livramentense reinventada pelo turismo: passos de uma pesquisa. Revista do Instituto Histórico e Geográfico de Mato Grosso: Dossiê Patrimônio. Ano 70, p. 31-46, 2012.

BRASIL. Agência Nacional de Águas. Ministério do Meio Ambiente. Superintendência de Planejamento de Recursos Hídricos. Atlas Brasil: Abastecimento Urbano de Água: Panorama Nacional. V1. Brasilia: Engecorps/Cobrape, 2010. 72p.

BRASIL. Fundação Nacional de Saúde. Manual de Cloração de Água em Pequenas Comunidades Utilizando o Clorador Simplificado Desenvolvido pela Funasa / Fundação Nacional de Saúde. - Brasília: Funasa, 2014. 36 p.

BRASIL. Lei no 14.026. De 15 de julho de 2020. Atualiza o 
Marco Legal do Saneamento Básico e Altera a Lei no 9.984, de 17 de julho de 2000. Disponível em: http://www.in.gov.br/en/web/dou/-/lei-n-14.026-de-15de-julho-de-2020-267035421. Acesso em: 18 jul. 2020.

BRASIL. MINISTÉRIO DAS CIDADES. IBGE - Instituto Brasileiro

de Geografia e Estatística. Pesquisa Nacional de Saneamento Básico - 2008. Agosto 2010. Disponível em: 138

http://www.ibge.gov.br/home/estatistica/populacao/con dicaodevida/pnsb2008/PNSB_2008.pdf. Acesso em: 10 ago. 2011.

BRASIL. Ministério do Desenvolvimento Regional. Secretaria Nacional de Saneamento - SNS. Sistema Nacional de Informações sobre Saneamento: 24ำ Diagnóstico dos Serviços de Água e Esgotos - 2018. Brasília: SNS/MDR, 2019. $180 \mathrm{p}$.

BRASIL. Portaria de Consolidação $\mathbf{n}^{\circ} \mathbf{5}$ do Ministério da Saúde. De 28 de setembro de 2017 -Anexo XX. Dispõe sobre o controle e vigilância da qualidade da água para consumo humano e seu padrão de potabilidade; incorpora a Lei PRT MS/GM 2914/2011. Disponível em: https://bvsms.saude.gov.br/bvs/saudelegis/gm/2017/prc 0005_03_10_2017.html. Acesso em: 10 abr. 2020.

BURLINGAME, G.A.; ANSELME, C. Distribution system tastes and odors. In: SUFFET, I.H.; MALLEVILLE, J.; KAWCZYNSKI, E. (eds.) Advances in taste-and-odor treatment and control. Denver: American Water Works Association Research Foundation and Lyonnaise des Eaux, 1995. p. 281-319.

CLARK, R. ROSSMAN, L.A.; WYNER, L. J. Modeling distribuition system water quality: Regulatory implications. Jouranl of Water Resources Planning and Management, v.121, p.423-428, 1995.

CUSTÓDIO, E.; LLAMAS, M. R. Hidrologia subterrânea. Barcelona: Editora Omega, 1983. 1157p.

DEGRÉMONT, G. C. Water Treatment Handbook, John Wiley \& Sons: New York, 1979.

DINIZ, J. A. O. MONTEIRO,A. B.; SILVA, R. C.; PAULA, T. L. F. Manual de Cartografia Hidrogeológica . Recife: CPRM Serviço Geológico do Brasil, 2014. 119p.

FERNANDES, L. L.; GOIS, R. V. Avaliação das principais metodologias aplicadas às análises microbiológicas de água para consumo humano voltadas para a detecção de coliformes totais e termotolerantes. Revista Científica da Faculdade de Educação e Meio Ambiente, v.6, n.2, p. 4964, 2015.

FONSECA, F. V.; ESTEVES, F. A.;FIGUEIREDO, I. C.; VOLSCHAN JR., I; PICÃO, R. C.; AZEVEDO, S. M. F. O. Nota Técnica da UFRJ sobre os problemas da qualidade da água que a população do Rio de Janeiro está vivenciando. Universidade Federal do Rio de Janeiro, janeiro de 2020,
$4 p$.

GALVÃO, H. L. Papa-bananas ilustres: síntese biográfica. Cuiabá: Central do Texto, 2010. 222p.

GARCIA, R. A. L.; VALENTINI, C. M. A.; FARIA. R. A. P. G. Aspectos ambientais do córrego Barbado em Cuiabá-MT. Enciclopédia Biosfera, v.1, n.22; p.243-263, 2015.

GICQUEL, A., JAEGER, Y.; LEGER, J. Veolia EAU - Direction Technique. Document Interne. Le réseau de distribution d'eau potable: déchloration, recholration, et modélisation. Nota Técnica, Abril de 2007.

JACOMINE, P.K.T. CASTRO; CASTRO FILHO, C.; MOREIRA, M.L.C.; VASCONCELOS, T.N.N.; SOBRINHO, J.B.P.L.; MENDES, A.M.; SILVA, V. Guia para Identificação dos Principais Solos do Estado de Mato Grosso. Cuiabá. NUD/PRODEAGRO. 1995. 118p.

LIBÂNIO, M. Fundamentos de qualidade e tratamento de ág ua. 4a ed. Campinas; Átomo, 2016. 638p.

LIMA, E. B. N. R.; MODESTO FILHO, P. M.; MOURA, R. M. P. (organizadores). Plano Municipal de Saneamento Básico: Nossa Senhora do Livramento-MT. Cuiabá: EdUFMT, 2017. 703p.

MACIEL DA SILVA, C. F. Nossa Senhora do Livramento: Santuário do Pantanal Mato Grossense. Cuiabá: Carlini \& Caniato. 2016. 142p.

MAITELLI, G. T. Uma abordagem tridimensional de clima urbano em área tropical continental: o exemplo de Cuiabá/MT. 1994. 204p. Tese (Doutorado em Geografia). Universidade de São Paulo, São Paulo, 2004.

MANZIONE, R. L. Águas Subterrâneas: conceitos e aplicações sob uma visão multidisciplinar. Jundiaí: Paco Editorial: 2015. 388p.

McGUIRE, M. Off-flavor as the consumer's measure of drinking water safety. Water Science and Technology, v. 31, n. 11, p.1-8, 1995.

MEYER, S. T. O uso de cloro na desinfecção de águas, a formação de trihalometanos e os riscos potenciais à saúde pública. Caderno de Saúde Pública, v.10, p.99110, 1994.

MIRANDA, A. B.; TEIXEIRA, B. A. N. Indicadores para o monitoramento da sustentabilidade em sistemas urbanos de abastecimento de água e esgotamento sanitário. Engenharia Sanitária e Ambiental, v. 9, n. 4, p. 219-228, 2004.

ORGANIZAÇÃO PAN-AMERICANA DA SAÚDE. Fascículo água: a desinfecção da água. Brasília: Opas, 1999.

PALUDO, D. 2010. 77f. Qualidade da água nos poços artesianos do município de Santa Clara do Sul. Monografia de Conclusão de Curso de Química Industrial. Centro Universitário Univates, Lajeado-RS, 2010.

PIVELI, R. P. Curso: “Qualidade das águas e poluição: aspectos físico-químicos". Notas de Aula, EEUSP. 2001. 
25p. Disponível em:

http://www.leb.esalq.usp.br/leb/disciplinas/Fernando/le b360/Fasciculo\%205\%20-

\%20Caracteristicas\%20Fisicas\%20das\%20Aguas.pdf

Acesso em: 5 abr. 2020.

SILVA, A. M.; VALENTINI, C. M. A. Abastecimento público de água no município de Nossa Senhora do Livramento-MT: ontem e hoje. Biodiversidade, v.16, n.1, p.64-100, 2017.

THOMPSON, T.; FAWELL, J.; KUNIKANE, S.; JACKSON, D.; APPLEYARD, $S$. et al. Chemical safety of drinking water: assessing priorities for risk management. Genebra: WHO, 2007.

TUCCI, C. E. M. Águas Urbanas. Estudos Avançados, v. 22, n. 63, p.97-112, 2008.

VALENTINI, C. M. A.; LIMA, S. M.; ZAQUE, R. A. M.; SOUZA, F. S. C.; PRISCILA MACHADO FERREIRA ALBANO, P. M. F.; BENEVENTO, G, P. Água de beber: um olhar sobre a possibilidade do reuso da água de ar-condicionado para fins potáveis. Biodiversidade, n.18, v.3, p.2-36, 2019.

VASCONCELOS, J. G.; KOIDE, S. Metodologia para Otimização da Amostragem de Qualidade de Água em Redes de Distribuição. Revista Brasileira de Recursos Hídricos, v.14, n. 4, p.5-15, 2009.

VIEIRA, P. C. C. 2016. 103f. Patologias em instalações hidrosanitárias de edifícios residenciais na zona centro-sul de Manaus (AM): diagnóstico e terapia. Dissertação (Mestrado Profissional) Programa de Pós-Graduação em Engenharia de Processos. Universidade Federal do Pará, Belém-PA. 2016.

WHO - WORLD HEALTH ORGANIZATION. Guidelines for drinking-water quality. 3. ed. Genebra, 2004. p. 210-220.

Submissão: 22/07/2020

Aprovado para publicação: 25/09/2020 